Przegląd Prawa Konstytucyjnego

----ISSN 2082-1212-----

DOI 10.15804/ppk.2021.06.40

-----2021, No. 6 (64)-----

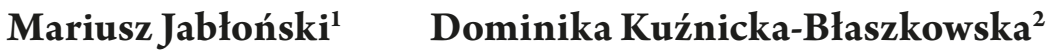

\section{"Disproportionate Effort" in the Meaning of Article 14 of the General Data Protection Regulation}

Keywords: data protection, indefinite phrases, privacy protection, disproportionate effort, GDPR

Słowa kluczowe: ochrona danych, klauzule niedookreślone, ochrona prywatności, niewspółmiernie duży wysiłek, RODO

\begin{abstract}
One of the main goals of the General Data Protection Regulation was to harmonize the way personal data is being protected in all Member States. This goal will not be achieved if a similar interpretation of its provisions does not accompany the application of the GDPR. It is particularly important when meaning is assigned to an indefinite phrase that different authorities and entities can understand variously as they apply the same law in each Member State. The phrase in question is that of "disproportionate effort" as used in Art. 14 para. 5 letter $b$ of the GDPR. The article is intended to provide an exemption from complying with the controller's obligation to provide information (where personal data have been obtained indirectly). Since the right to be informed about collecting and using personal data is one of the fundamental rights granted to the data subject un-
\end{abstract}

1 ORCID ID: 0000-0001-8347-1884, professor, Department of Constitutional Law, Faculty of Law, Administration and Economics, University of Wrocław E-mail: mariusz. jablonski@uwr.edu.pl.

2 ORCID ID: 0000-0001-8804-569X, Ph.D., Department of Constitutional Law, Faculty of Law, Administration and Economics, University of Wrocław E-mail: dominika.kuznicka@ uwr.edu.pl. 
der the GDPR, a uniform application of the standard laid down in Art. 14 of the GDPR is of importance to ensure.

\section{Streszczenie}

\section{„Niewspółmiernie duży wysiłek” w rozumieniu art. 14 Ogólnego rozporządzenia o ochronie danych osobowych}

Jednym z głównych celów RODO jest ujednolicenie zasad ochrony danych osobowych we wszystkich państwach europejskich. Cel ten nie zostanie jednak osiągnięty, jeśli stosowaniu rozporządzenia nie będzie towarzyszyła zbliżona interpretacja jego przepisów. Jest to szczególnie istotne w przypadku zwrotów niedookreślonych, które mogą być w różny sposób rozumiane przez organy stosujące prawo w państwach członkowskich. Jednym z tychże jest przesłanka „niewspółmiernie dużego wysiłku” wskazana w art. 14 ust. 5 lit. b RODO umożliwiająca uchylenie się od obowiązku informacyjnego w przypadku pozyskiwania danych osobowych od innych podmiotów niż podmioty danych. W związku z tym, że prawo do informacji na temat przetwarzanych danych osobowych jest jednym z podstawowych przyznanych jednostce na gruncie RODO, zapewnienie jednolitość stosowania normy określonej w art. 14 RODO jest szczególnie istotne.

\section{$*$}

\section{Foreword}

EU General Data Protection 3 is a "normative clamp" crowning many years of discussions on the protection of personal data in the legal system of the European Union ${ }^{4}$. The purpose of adopting this act is not only to harmonize the rules for the protection of personal data in all European countries but also to strengthen the protection of the freedoms and rights of persons whose data are processed. Considering Recital 7 of the GDPR, it can be pointed out that the regulation is therefore intended to provide a stable and coherent frame-

3 Regulation (EU) 2016/679 of the European Parliament and of the Council of April 27, 2016 on the protection of individuals with regard to the processing of personal data and on the free movement of such data, and repealing Directive 95/46/EC (EU General Data Protection Regulation, GDPR).

4 P. Carey, Data Protection: A practical guide to UK and EU Law, Oxford 2018. 
work for data protection in the European Union and provide public administrative bodies with tools to effectively enforce provisions in this respect.

However, this goal will not be achieved if a similar interpretation of its provisions does not accompany the application of the GDPR. It is particularly important when meaning is assigned to an indefinite phrase (a general clause) which can be understood differently by different authorities and entities as they apply the same law in each Member State. It is not unusual for both EU legislators and national lawmakers to resort to indefinite phrases. On the contrary, this practice is quite common and, in large part, justified by the expectation that such phrases will adequately deal with an extensive and diverse range of specific and complex factual situations to be tackled by a new law. This diversity and specificity are valid reasons for using such phrases to assert a public administration body of its right to handle a case objectively by considering the point of view of its subject, the underlying circumstances, and the consequences of any actions taken ${ }^{5}$.

The GDPR contains references to undefined phrases. Both the specificity and the nature of this regulation call for a solution that can dynamically respond to the different types of factual situations faced by the controllers at the practical level of data processing ${ }^{6}$. Given these observations, we would like our study to focus on one indefinite phrase used in the GDPR by the EU legislator. The phrase in question is that of "disproportionate effort" as used in Art. 14 para. 5 letter b of the GDPR. Since the right to be informed about collecting and using personal data is one of the fundamental rights granted

5 M. Zdyb, J. Stelmasiak, Zasady ogólne Kodeksu postępowania administracyjnego. Orzecznictwo Naczelnego Sądu Administracyjnego z komentarzem, Lublin 1992; Z. Radwański, M. Zieliński, Klauzule generalne w prawie prywatnym, [in:] System Prawa Prywatnego, ed. M. Safjan, vol. 1, Warsaw 2007; M. Śliwka, Znaczenie zwrotów niedookreślonych na tle orzecznictwa polskiego Trybunału Konstytucyjnego, "Studia Iuridica Lublinensia” 2010, vol. 13, pp. 261-272; J. Mojak, Dobre obyczaje w polskim prawie kontraktowym - wybrane zagadnienia, "Studia Iuridica Lublinensia” 2016, vol. 25, pp. 161-174; W. Mojski, Generalne klauzule odsyłające we wspótczesnym polskim prawie konstytucyjnym. Zarys problematyki, "Annales Universitatis Mariae Curie-Skłodowska” 2016, vol. LXIII, No. 2, pp. 151-160; A. Szot, Klauzula generalna jako ponadgałęziowa konstrukcja systemu prawa, "Annales Universitatis Mariae Curie-Skłodowska" 2016, vol. LXIII, No. 2, pp. 291-304.

6 C. Kuner, B. Svantesson, F.H. Cate, O. Lynskey, C. Millar, The language of data privacy law (and how it differs from reality), "International Data Privacy Law" 2016, vol. 6, No. 4. 
to the data subject under the GDPR, a uniform application of the standard laid down in Art. 14 of the GDPR is of importance to ensure. Through effective compliance with the obligation to inform on the part of the controller, those concerned may exert control over how their data are processed, and in case of a breach, they may lodge a complaint or take out an action. Hence a good reason to review the situations in which the controller will, on the premise that the effort seems disproportioned, be relieved of his or her obligation to inform the personal data subject about the processing.

The phrase unspecified "disproportionate effort" is further used in Art. 19 of the GDPR concerning relieving the controller from the obligations to inform in case of rectification or erasure of personal data and communicate a data breach to those concerned ${ }^{7}$. One cannot fail to notice that this premise crops up in the Regulation whenever it is incumbent on the controller to contact the group of entities whose data he processes. It is an example of a derogation from the principle of transparency in the processing of personal data ${ }^{8}$. It seems to be a logical consequence that such contact will entail considerable costs, especially when dealing with large groups of people. Nevertheless, it will also require an organizational effort and technical solutions.

\section{The Obligations of the Personal Data Controller Under Art. 14 GDPR and Their Importance for the Protection of the Rights of an Individual}

Personal data may, in principle, either come directly from the data subject or be transferred to the controller by third parties. In the latter case, undoubtedly, it is very important for the entity concerned to know its data process, its purpose, terms and conditions, and the data subject's rights. If a different assumption was adopted, it would lead to the processing of personal data without the individual's knowledge and thus depriving them of their right to protect their rights effectively. Regarding secondary data, i.e., any data obtained indirectly rather than from the data subject, the controller must provide the data subject with additional categories of information in connection

7 This phrase was also used in Art. $34 \mathrm{sec} .3$ (c).

8 The General Data Protection Regulation: Guidance on Lawful Processing, Information Governance Allians. 
with the personal data processing. The information obligations lying both with the controller and the processor make one of the pillars on which the personal data protection law rests. With the data subject obtaining the information under Art. 13 and 14 of the GDPR, it is possible to put the idea of the individual's informational autonomy into effect ${ }^{9}$. Providing information under Art. 14 is necessary to ensure the success of any action taken against the infringement of one's right to protect personal data or lodge a complaint with the competent authority. The preceding precautions allow the data subject to verify the lawfulness of the processing and examine whether the conditions have been satisfied or not to ensure the accuracy and transparency of personal data processing.

The makers of the GDPR have noticed that an individual does not necessarily require to be provided with the complete set of information to have their data adequately protected. If the data subject has already obtained the information, the obligation imposed on the controller under Art. 14 does not have to be observed. The acquisition or disclosure of the information is expressly governed by Union law or Member State law to which the controller is subject. The majority of the conditions that need to be satisfied to fulfill the obligation to inform under Art. 14 do not seem to require an extensive commentary because the regulators have clearly defined their scope and content. Nonetheless, the problem arises when the controller is exempted from the obligation to provide information if the provision of such information proved impossible or involved a disproportionate effort.

The GDPR does not define "disproportionate effort" - the term referred to in Art. 14. Bearing in mind that in the case of secondary data collection, a disproportionate effort is one of the conditions to be satisfied to relieve the controller of his or her obligation to inform, it is vital to properly and thoroughly understand what to assess and how to determine whether complying with the obligation laid down in Art. 14 does or does not involve a disproportionate effort. The concept carries a two-fold meaning. It limits the individual's rights concerning their right to obtain information on those who process their personal data, the purpose of such processing, and the data

\footnotetext{
9 E. Bielak-Jomaa, D. Lubasz, RODO. Ogólne rozporządzenie o ochronie danych. Komentarz,
} Warsaw 2018. 
used in the process. Given the latest case-law of the ECHR and the CJEU, the rights and freedoms may not be limited or restricted unless such limitation or restriction enables the achievement of a pre-set goal in complete satisfaction of the principle of proportionality. Unable to obtain the information about those who process his or her personal data, the data subject will, in case of a breach, be practically prevented from requesting the discontinuance of data processing or from filing a complaint with the relevant supervisory authority. It leads to some fiction. Endowed with the authority under the GDPR, the individual has no power to exercise it in practice (e.g., to file a civil claim or initiate administrative proceedings as in either case the data subject will need information on the defendant or the infringer), which weakens the assurances laid down in the GDPR and lessens the social impact of the law. A legal instrument can only implement a restriction on the rights of an individual. Therefore, it is reasonable to seek a more precise definition of the premise that the obligation to inform is prescribed in Art. 14 GDPR may be removed.

On the other hand, big actors, economic operators of scale, or large organizations will find the GDPR solution "convenient", for they can easily divest themselves of the obligation to inform by invoking the premise of disproportionate effort. Without an unambiguous definition, the situations which can be considered as requiring disproportionate effort make up a wide-ranging catalog. Financial, organizational or technical matters may depend on them, and the larger the entity, the greater the organizational effort, expenditure of time, and the extent of financial outlays it has to exert, incur and require fulfilling the obligation to inform. It may lead to favoring large entities and result in unequal treatment of smaller ones. The latter will struggle to process large amounts of personal data often because of the constraints arising from the nature of their business. Therefore, in theory, fulfilling the obligation to inform should become simpler with no involvement of disproportionate effort.

It is important to employ the argument of disproportionate effort to circumscribe the information obligations when the controller of personal data has practically no relationship with the data subject during the processing, for example, in the case of electronic equipment suppliers and mobile phone service providers processing IP numbers during roaming. The controller is not expected to contact data subjects, and the data is processed to perform 
the $\mathrm{B} 2 \mathrm{~B}$ contract. In the era of the modern digital economy, the situation evolves on a considerable scale. If every company that collects data from external controllers were to contact each individual directly, it would flood data subjects with communications and cause much frustration and confusion. Uncontrolled, the obligation to inform will hardly serve any public interest.

In practice, it is tough to identify situations in which the disproportionate effort exception applies. The lack of interpretative guidelines (apart from recital 62) in the GDPR means that this issue is left at the discretion of the courts and law enforcement bodies.

\section{Understanding the Disproportionate Effort in the Judicial Practice of the CJEU and National Data Protection Authorities}

As a premise on which the fulfillment of the obligation to provide information is deemed unnecessary under Art. 14, the disproportionate effort requires further interpretation. The article in question points out situations that could involve a disproportionate effort, particularly in the case of processing for archiving purposes in the public interest, scientific or historical research purposes, or for statistical purposes subject to the conditions and safeguards referred to in Art. $89 \mathrm{sec} .1$ or in so far as the information obligation may prevent or seriously impede the achievement of the purposes of such processing.

It seems that "disproportionate effort" can be understood as a situation in which the effort implemented in providing the information is unequal to the inconvenience caused by the lack of this information in the data subject ${ }^{10}$. In this case, the smallest difficulty associated with implementing the obligation (financial, organizational, technical) can easily be considered to require a disproportionate effort. Therefore, it is important to specify additional criteria that should be taken into account when interpreting the concept of disproportionate effort. Each time, however, the conditions for dismissal are updated

10 P. Carey, Data Protection: A practical...; Guide to the General Data Protection Regulation (GDPR) Data protection, Information Commissioner's Office, https://ico.org.uk/for-organisations/guide-to-data-protection/guide-to-the-general-data-protection-regulation-gdpr (20.06.2021). 
in cases where informing the data subject would mean a special, above-standard, unjustified, in specific circumstances involvement of the controller ${ }^{11}$.

Recital 62 of the GDPR states that the assessment of disproportionate effort can be carried out by considering the number of data subjects, the period of data storage, and any appropriate safeguards adopted. This quantifier should be evaluated objectively on every occasion with due regard to the situation of a particular controller ${ }^{12}$. The Art. 29 Working Party emphasizes that when determining what amounts to an impossibility or a disproportionate effort, it is important to ascertain that no comparable exclusions under Art. 13 (when personal data is collected from the data subject) apply to ensure that the factors responsible for disproportionate effort arise directly from the fact that the personal data has been collected from elsewhere rather than the data subject ${ }^{13}$. In the Working Party's opinion, if the controller intends to invoke a disproportionate effort to divest him- or herself of the obligation to inform, he or she should carry out a balance test to compare the effort put by the controller in providing information to the data subject with the consequences the person concerned will take if they are denied access to this type of information. Considering the principle of accountability, the controller should document the assessment. The controller is also obliged to apply appropriate protection measures to ensure the protection of the freedoms and rights of an individual. One such measure is a public announcement placed on a website, in a newspaper, or via other means of communication to inform about a personal data processing exercise.

The situation implying the disproportionate effort exception is one in which compliance with the obligation to inform would result in losses in the further functioning of the entity or preventing the fulfillment of the purposes of data processing. Such situations may include, for example, a notification about the processing of hacker or fraudster data, an employee who will lead to a leak of

11 B. Fischer, Komentarz w sprawie nałożenia pierwszej $w$ Polsce kary za naruszenie RODO, https://www.chwp.pl/nowosci-i-komentarze/komentarz-w-sprawie-nalozenia-pierwszej-wpolsce-kary-za-naruszenie-rodo (20.06.2021).

12 Rozporządzenie UE w sprawie ochrony osób fizycznych w związku z przetwarzaniem danych osobowych i swobodnym przeptywem takich danych. Komentarz, eds. P. Litwiński, P. Barta, M. Kawecki, Warsaw 2018.

13 Art. 29 Working Party "Guidelines on transparency under Regulation 2016/679" WP260 rev. 01, November 29, 2017. 
information about a company secret or its intellectual property ${ }^{14}$. Situations in which data are processed in a generally acceptable manner, considering existing practices and rational premises, should also be considered requiring disproportionate effort. Examples could include an employee informing his employer who should be notified in case of an accident or informing a financial institution or an insurer about the beneficiaries of accumulated funds in case of the principal's death ${ }^{15}$.

The CJEU has not yet allotted time to construe the premise of disproportionate effort based on the GDPR, but as an indefinite clause, this phrase was present in the previous directive and cropped up in different contexts in the EU secondary legislation. Therefore, it seems reasonable to avail oneself of the reference literature produced by law enforcement bodies to date to explore the conceptual scope of the premise of disproportionate effort.

For example, the CJEU held that an effort to review forty-seven thousand pages of documents to make them available under the right of access to public information should be considered disproportionate ${ }^{16}$. In the context of Art. $14 \mathrm{sec} .5$ (b) GDPR, the ruling is a premise on which the obligation to inform can be limited because a large number of personal data subjects require notification that their data were processed. The Recital 62 of the GDPR reflects the same approach.

Basing on Directive 95/46/EC, the CJEU also indicated that before embarking on any action on the premise of disproportionate effort, both the number of personal data subjects whose data are processed and the organizational capacity of the controller must be reviewed. Furthermore, the data in the process should be assessed for their age (potential outdating). It is also necessary to examine whether the controller has applied appropriate technical

14 Centre for Information Policy Leadership Response, Consultation by the Irish Data Protection Commissioner on the Topics of Transparency and International Data Transfers under the GDPR, 13.10.2017, https://www.informationpolicycentre.com/uploads/5/7/1/0/57104281/ cipl_response_to_irish_dpc_consultation_on_transparency_and_international_data_transfers_under_the_gdpr.pdf(20.06.2021); A. Bussche Freiherr; A. Zeiter, Implementing the EU General Data Protection Regulation: A Business Perspective, 2 Eur. "Data Protection Law Review" 2016, No. 576.

15 Centre for Information Policy Leadership Response...

16 Verein für Konsumenteninformation v Commission of the European Communities, $\mathrm{T}-2 / 03$. 
and organizational measures which, considering state of the art in this field and the cost of implementation, ensure an appropriate level of security to the risks arising from data processing and the nature of the data being protected ${ }^{17}$.

The Polish Personal Data Protection Office (UODO) decision of March 15, $2019^{18}$ is one of the first to have acknowledged an incident of breach of the information obligation in case of secondary acquisition of personal data. The database of the company in subject contained information on more than 3.5 million people who at the time had or suspended business activities and 2.3 million natural persons who had engaged in business in the past. The company fulfilled its obligation to inform only less than a million entrepreneurs. Concerning the remaining data stock, the company decided that sending text messages or traditional mail letters to the people whose e-mail addresses it did not know would be too expensive and require a disproportionate effort. In the opinion of the UODO President, sending information under Art. 14 of the GDPR by traditional mail to the address of a natural person conducting a business activity or contacting his or her on the telephone was not an "impossible" exercise or an operation involving a "disproportionate effort", especially when the company in question owned the address details of the (past and present) sole traders or self-employed individuals and in some cases also of their telephone numbers. The UODO emphasized that with the company owning correspondence addresses sending the information by registered mail would not be necessary "if only the controller could demonstrate with good evidence that the obligation to inform had been fulfilled by him or her to the satisfaction of the data subjects whose personal data were being processed". The situation would have differed if the company had not held telephone numbers or correspondence addresses of the persons whose data were processed $^{19}$. With the large number of the data subjects, the disproportionate effort exception would have applied in this case if the contact details had had to be collected first in order to subsequently enable the fulfillment of the obligation to inform. However, it does not matter whether the contact information is publicly available or not - this condition may still be attached if the data were to be obtained from public registers. In like circumstances, there is

\footnotetext{
17 College van burgemeester en wethouders van Rotterdam v M.E. E. Rijkeboe, C-553/07.

18 ZSPR.421.3.2018.

19 I OSK $1827 / 11$.
} 
no option to claim any "impossibility" of fulfilling the obligation to inform in justified situations, one can only point to a disproportionate effort as a release condition ${ }^{20}$. The court overruled the decision of UODO in December $2019^{21}$. However, the court agreed with UODO that the high costs of its implementation should not explain disproportionate effort. High costs are not the same as a disproportionate effort, but only such a circumstance would justify waiving the obligation to provide information in the described case. The publication of an information clause on the website proved to be insufficient. It is worth mentioning that there are proceeding against the same company being conducted in Czech and Slovakia. However, local authorities have not granted any ruling yet.

The jurisprudence that would elucidate Art. $14 \mathrm{sec} .5$ (b) is still underdeveloped. Nonetheless, we have compiled a catalog of conditions and situations that sanction the refusal to fulfill the obligation to inform. They include without limitation: a large number of subjects whose data is processed, difficulties or inability to obtain data subjects' contact information, minimum risk of a personal data breach, the use of data for the sole purpose of recognizing established local customs. It is an open catalog with no requirement to meet all the conditions at the same time. However, the administrative authority must examine if the fulfillment of the obligation to inform is proportionate to the inconvenience caused by the lack of this information in the data subject or the organizational effort and technical measures to be employed to ensure the security of processed data.

That leads to the following conclusions:

- the evaluation of whether "disproportioned effort" is involved or not is based on a specific model of personalized characteristics that considers both the subjective (form of organization) and objective aspects of the controller's profile. This approach leaves no doubt that similar facts pertaining to different controllers may be given entirely different assessments by the national data protection authority at the first instance or should an appeal be granted by the competent court of law.

- in each particular case, acting on the premise that he or she may

20 P. Kozik, Niewspótmiernie duży wysitek w realizacji wtórnego obowiązku informacyjnego, “ABI Expert” 2019, vol. 2.

${ }^{21}$ II SA/WA 1030/19. 
invoke/apply the "disproportionate effort" exception, the controller shall demonstrate rationally with objective evidence to substantiate his or her assertion that he would be required to expend additional organizational effort, including human resources (e.g., hire more staff) and materials (e.g., purchase new hardware or software), and therefore incur high costs, the amount of which should be related to the standard operating costs of the controller.

\section{Conclusions}

The obligation to inform is laid down in Art. 14 of the GDPR is one of the guarantees of personal data protection to enable the effective protection of the rights and freedoms of an individual. At the same time, the lawmakers have limited this right by building in conditions that allow the controller to escape this obligation. Of these, the greatest interpretation doubt arises as to a "disproportionate effort" specified in Art. 14 sec. 5 (b). This premise may relate to processing for archival purposes in the public interest, scientific or historical research, or statistical ones. At the same time, the catalog of exceptions does not exhaust all the possibilities of relying on the premise. As a result, by using undefined standards, i.e., the premise of disproportionate effort, the legislator has given considerable discretion to the authorities applying the law. On the one hand, this allows for flexibility as the law is applied, but on the other hand, especially at the initial stage of application, it leads to legal uncertainty. A solution of this nature may produce the illusion that the rights of an individual are protected, but it does not provide any guarantees. The obligation to inform has strong links with the information autonomy of an individual. Therefore, it is also important to adequately incorporate this obligation into law to ensure effective control over personal data processing as regards the scope and manner of the process.

Situations that seem to justify the use of the premise of disproportionate effort may include both the processing of a vast amount of data, but only if linking them with the data subject's information was impossible. The argument that the processing of large amounts of data necessitates 
the obligation to inform large numbers of data subjects does not suffice. The controller invokes Art. 14 sec. 5 (b) only if he or she is unable to link personal data to the correspondence address (be it a traditional mail address or an e-mail address). The application of this provision may also be justified in the context of individual processing where social considerations or any customs prevailing in a given legal system should be taken into account, for example, providing the employer with the data subject's next-of-kin or the closest one's personal data to contact them in case of threat to the employee's life or health. Escaping the obligation to inform also seems justified when the processing of personal data does not infringe on the interest of an individual, and there is no possibility of damage to be caused by the processing.

If the controller intends to apply the disproportionate effort exception, he or she should carry out an individual analysis of the scope and nature of the activities, which must be covered by the obligation to inform the data subject whose data are processed. The controller must also review all risks relating to the situation where the data subject has no information. It is necessary to determine whether the lack of information would adversely affect protecting the individual's rights. If so, the next step is the proportionality exercise considering the compliance of the fulfillment of the obligation with the obligation to inform. In addition, the controller is required to employ other organizational and technical measures to guarantee the security of personal data being processed. It means, among others, that the information about the processing of personal data of a specific origin and type has to be disclosed to the public either on the controller's website or through traditional means of communication. It seems that the controller should choose a way of public announcement that will ensure reaching the largest number of natural persons whose data are processed. The choice of the controller may vary depending on who data subjects are, whose data is processed, which social group they represent, and what communication tools they use. In terms of providing other measures to guarantee the security of processed data, the absolute minimum seems to fulfill the obligation under Art. 32 GDPR and other provisions of the Regulation. 


\section{Literature}

Bielak-Jomaa E., Lubasz D., RODO. Ogólne rozporzadzenie o ochronie danych. Komentarz, Warsaw 2018.

Bussche Freiherr A., Zeiter A., Implementing the EU General Data Protection Regulation: A Business Perspective, 2 Eur. "Data Protection Law Review" 2016, No. 576.

Carey P., Data Protection: A practical guide to UK and EU Law, Oxford 2018.

Fischer B., Komentarz w sprawie nałożenia pierwszej w Polsce kary za naruszenie RODO, https://www.chwp.pl/nowosci-i-komentarze/komentarz-w-sprawie-nalozenia-pierwszejw-polsce-kary-za-naruszenie-rodo/

Jakimowicz W., Wykładnia w prawie administracyjnym, Zakamycze 2006.

Kozik P., Niewspótmiernie duży wysitek $w$ realizacji wtórnego obowiązku informacyjnego, "ABI Expert" 2019, vol. 2.

Mojak J., Dobre obyczaje w polskim prawie kontraktowym - wybrane zagadnienia, "Studia Iuridica Lublinensia" 2016, vol. 25.

Mojski W., Generalne klauzule odsyłające we współczesnym polskim prawie konstytucyjnym. Zarys problematyki, "Annales Universitatis Mariae Curie-Skłodowska" 2016, vol. LXIII, No. 2.

Ochrona danych osobowych. Komentarz, eds. J. Barta, P. Fajgielski, R. Markiewicz, Kraków 2011.

Pomorska A., Kontrowersje wokót przesłanek umorzenia zaległości podatkowych, [in:] Ex iniuria non oritur ius. Księga ku czci Profesora Wojciecha Łaczkowskiego, eds. A. Gomułowicz, J. Małecki, Poznań 2003.

Radwański Z., Czy klauzula generalna społeczno-gospodarczego przeznaczenia prawa powinna określać treść prawa własności, [in:] ARS ET USUS. Księga pamiątkowa ku czci Sędziego Stanisława Rudnickiego, Warsaw 2005.

Radwański Z., Zieliński M., Klauzule generalne w prawie prywatnym, [in:] System Prawa Prywatnego, ed. M. Safjan, vol. 1, Warsaw 2007.

Rozporzadzenie UE w sprawie ochrony osób fizycznych $w$ związku z przetwarzaniem danych osobowych i swobodnym przeptywem takich danych. Komentarz, eds. P. Litwiński, P. Barta, M. Kawecki, Warsaw 2018.

Szot A., Klauzula generalna jako ponadgatęziowa konstrukcja systemu prawa, "Annales Universitatis Mariae Curie-Skłodowska" 2016, vol. LXIII, No. 2.

Śliwka M., Znaczenie zwrotów niedookreślonych na tle orzecznictwa polskiego Trybunatu Konstytucyjnego, "Studia Iuridica Lublinensia" 2010, vol. 13.

Voigt P., von dem Bussche A., The EU General Data Protection Regulation (GDPR). A Practical Guide, Springer 2017.

Zdyb M., Stelmasiak J., Zasady ogólne Kodeksu postępowania administracyjnego. Orzecznictwo Naczelnego Sąu Administracyjnego z komentarzem, Lublin 1992. 